\title{
Risk factors for colonization and infection by multiresistant bacteria
}

\author{
S Carvalho Brugger ${ }^{1 *}$, R Gavilan Rabell ${ }^{2}$, M Miralbes Torner ${ }^{2}, \mathrm{G}$ Jimenez Jimenez ${ }^{2}$, S Iglesias Moles², \\ J Trujillano Cabello², M Vallverdú Vidal², B Balsera Garrido², F Barcenilla Gaite², M Palomar Martínez² \\ From ESICM LIVES 2015 \\ Berlin, Germany. 3-7 October 2015
}

\section{Introduction}

In 2013, the "Zero Resistance" (RZ) program was launched in Spain, to help prevent the emergence of multiresistant bacteria (MRB) in critically ill patients. One of its recommendations is to complete a checklist upon patient admission in Intensive Care Unit (ICU) to identify those patients at high risk for colonization or infection by MRB*.

\section{Objectives}

To analyse the effectiveness of the checklist proposed as a way to early detect MRB and the role of other comorbidities.

\section{Methods}

A prospective study from March $17^{\text {th }}, 2014$ to January $31^{\text {rst }}, 2015$. All patients admitted to a polyvalent ICU of a general hospital were submitted to the checklist proposed, with the application of contact precaution $(\mathrm{CP})$ strategies for patients with risk factors (RF) for colonization or infection by MRB. Bacteriologic swabs (nasal, pharyngeal, axillary and rectal) were routinely performed on all patients admitted, besides diagnostic cultures when they were necessary. Furthermore, we analysed other pathological variables and comorbidities (diabetes, renal failure, immunosuppression state, neoplasia, cirrhosis, chronic obstructive pulmonary disease -COPD-, organ transplantation, malnutrition and type of admission to ICU - urgent or programmed). Univariate and multivariate analysis of risk factors for MRB with binary logistic regression were performed. Statistical significance was set at CI 95\%.

${ }^{1}$ Hospital Universitari Arnau de Vilanova, Lleida, Spain

Full list of author information is available at the end of the article

\section{Results}

780 patients were admitted. $231(29,6 \%)$ met some CP criteria. In $78(10 \%)$ were detected one or more MRB, 49 of these $(62,8 \%)$ presented CP criteria according to the checklist. 23 met 1 criteria, 17 met 2 criteria and 10 met 3 or more criteria with accumulation of risk. In 29 (37, 2\%) MRB carriers it was not identified any of the RF from the checklist. Tables 1 and 2 show RF and comorbidities that were significant as added risk for MRB. We did not find significant relation between renal failure, immunosuppression state, neoplasia, cirrhosis or organ transplantation and being MRB carrier.

Table 1. RZ checklist

\begin{tabular}{lll}
\hline RZ CHECK LIST & $\begin{array}{l}\text { OR (IC 95\%) } \\
\text { UNIVARIATE }\end{array}$ & $\begin{array}{l}\text { OR (IC 95\%) } \\
\text { MULTIVARIATE }\end{array}$ \\
\hline $\begin{array}{l}\text { Hospitalization }>5 \text { days in prior } \\
3 \text { months }\end{array}$ & $3,2(2,0-5,2)$ & $2,05(1,1-3,7)$ \\
\hline Institutionalized patient & $3,7(1,6-8,6)$ & NS \\
\hline Prior MRB colonization/infection & $14(5,7-34,4)$ & $8,7(3,3-22,9)$ \\
\hline $\begin{array}{l}\text { Antibiotherapy }>7 \text { days in prior } \\
\text { month }\end{array}$ & $4,2(2,5-7,2)$ & $2,1(1,1-4,1)$ \\
\hline $\begin{array}{l}\text { Chronic kidney disease with } \\
\text { dialysis }\end{array}$ & $1,5(0,2-12,7)$ & NS \\
\hline $\begin{array}{l}\text { Colonization susceptibility } \\
\text { (bronchiectasis, cystic fibrosis) }\end{array}$ & $2,0(0,7-5,5)$ & NS \\
\hline
\end{tabular}

Table 2. Comorbidities and type of admission

\begin{tabular}{lll}
\hline COMORBIDITY & $\begin{array}{l}\text { OR (IC 95\%) } \\
\text { UNIVARIATE }\end{array}$ & $\begin{array}{l}\text { OR (IC 95\%) } \\
\text { MULTIVARIATE }\end{array}$ \\
\hline DM type II & $1,9(1,2-3,1)$ & $1,8(1,1-3,1)$ \\
\hline COPD & $1,9(1,1-3,4)$ & NS \\
\hline Malnutrition & $1,9(1,1-3,6)$ & NS \\
\hline Urgent admission to ICU & $1,85(1,1-3,0)$ & NS \\
\hline
\end{tabular}




\section{Conclusions}

In our environment, the checklist did not detect $37 \%$ of patients with MRB. Prior antibiotic therapy and prior colonization were the best predictors. Further factors as diabetes could help on detection of MRB in ICU.

\section{Authors' details}

${ }^{1}$ Hospital Universitari Arnau de Vilanova, Lleida, Spain. ${ }^{2}$ Hospital Universitari Arnau de Vilanova., Lleida, Spain.

Published: 1 October 2015

\section{Reference}

1. Montero J, et al: (Scientific Expert Committee for the "Zero Resistance" Project). Combatting resistance in intensive care: the multimodal approach of the Spanish ICU "Zero Resistance" program. Critical Care 2015, 19(114)

doi:10.1186/2197-425X-3-S1-A126

Cite this article as: Carvalho Brugger et al:: Risk factors for colonization and infection by multiresistant bacteria. Intensive Care Medicine Experimental 2015 3(Suppl 1):A126.

\section{Submit your manuscript to a SpringerOpen ${ }^{\mathcal{O}}$} journal and benefit from:

- Convenient online submission

- Rigorous peer review

- Immediate publication on acceptance

- Open access: articles freely available online

- High visibility within the field

- Retaining the copyright to your article 